\title{
Identification of Tolerant Plant Species Growing Alongside National Highway-21 in Himachal Pradesh, India
}

\author{
Abhay Sharma ${ }^{1}$, Satish Kumar Bhardwaj ${ }^{1}$, Meena Thakur ${ }^{2}$, \\ Uday Sharma $^{3}$ and Subhash Sharma ${ }^{4}$
}

${ }^{1}$ Department of Environmental Science; ${ }^{2}$ Department of Entomology; ${ }^{3}$ Department of Soil Science and Water Management; ${ }^{4}$ Department of Social Sciences; YS Parmar University of Horticulture and Forestry, Nauni, Solan (H.P.), India

*Corresponding author

\section{A B S T R A C T}

Air pollution due to vehicular emissions has become a global tribulation for living organisms. Controlling air pollution is one of the complex environmental challenges. The only suitable ecological approach to control air pollution is constructing green belts in and

\section{Keywords}

Air pollution tolerance index, Biochemical parameters, Greenbelt, Indicators, Roadside plant species

\section{Article Info}

Accepted:

20 May 2018

Available Online:

10 June 2018 around the pollution sources. A field study was conducted during the year 2016-17 to assess the air pollution tolerance of plants growing alongside National Highway-21 in Himachal Pradesh. The registered distribution pattern studies indicated that six tree species namely Dalbergia sisso, Grewia optiva, Leucaena leucocephala, Toona ciliata, Morus alba and Ficus palmata were found commonly growing alongside the selected highway. In addition, five shrub species namely Adhatoda vasica, Vitex negundo, Murraya koenigii, Carissa opaca and Debregeasia hypoleuca were also selected. Based on air pollution tolerance index (APTI), among commonly growing trees Toona ciliata registered highest APTI value of 12.53 followed by Leucaena leucocephala with value of 11.05 . The tolerance level of these tree species was followed by Dalbergia sisso (10.56) > Grevia optiva (9.98) > Ficus palmata (9.94) > Morus alba (9.33). Also, tolerance level of shrubs was calculated which showed that among shrubs Adhatoda vasica and Murraya koenigii with APTI values (9.02 and 8.47) were found to be tolerant followed by Debregeasia hypoleuca (7.98) > Carissa opaca (7.96) > Vitex negundo (7.79). Overall results indicated that Toona ciliata and Leucaena leucocephala among tree species and Adhatoda vasica and Murraya koenigii among shrub species registered relatively higher tolerance level than other species. Therefore, should be recommended for the plantation alongside highways to reduce air pollution.

\section{Introduction}

Transport sector is a catalyst which leads to economic development of any nation and the rapid growth of motor vehicle impose a great threat on environment. In India, $60-70 \%$ of the air pollution is caused by transport sector followed by industries (Khandar and Kosankar 2014; Sisodia and Dutta 2016). Air pollution due to vehicular emissions has become one of 
the most serious problems in the whole world and has resulted in huge threat to both the environment and the health of living organisms. The major pollutants emitted from exhaust emission of gasoline fuelled vehicles are $\mathrm{CO}, \mathrm{HC}, \mathrm{NOx}$ and $\mathrm{Pb}$, while pollutant from diesel fuelled vehicles are particulate matter (including smoke), $\mathrm{SO}_{2}, \mathrm{PAH}$, which play a great role in determining ambient air quality of surrounding areas (Gidde and Sonawane 2012).

Continuous increase in the vehicular pollution has resulted in deterioration of fresh air and has exerted a deep influence on the morphological (leaf number, leaf area, stomata number, stomata structure, flowering, growth, and reproduction), biochemical parameters, such as the ascorbic acid content, chlorophyll content (Sharma et al., 2017a) and physiological parameters (leaf extract $\mathrm{pH}$ and relative water content) of roadside plants (Seyyednejad et al., 2011; Pandit et al., 2017).

The degradation of air quality is a major environmental crisis that affects the surrounding regions. So, the only suitable ecological approach to control air pollution is plants. Plants are the prime receivers of different types of pollutants, act as a green belt component and a sink by cleaning the atmosphere (Sharma et al., 2017b). Plant cleans the atmosphere through the mechanism of absorption, adsorption, accumulation and detoxification, which not only control air pollution but also improve air quality by providing sufficient amount of oxygen to the atmosphere (Mondal et al., 2011; Kapoor and Bhardwaj 2016). Development of green belt, by plantation of tolerant plant species, can mitigate air pollution, prevent soil erosion and create aesthetic environment and for this, selection of plant species is an important factor to be considered. Screening of tolerant plant species was done on the basis of air pollution tolerance index (APTI) which includes four parameters (ascorbic acid, total chlorophyll content, relative water content and $\mathrm{pH})$.

\section{Materials and Methods}

\section{Site description}

The present study was conducted in National Highway-21 (now NH-154) also known as Kiratpur - Nerchowk Expressway during the year 2016-17. The present highway in Northern India connects Chandigarh to the popular tourist places like Kullu and Manali in Himachal Pradesh which has caused heavy traffic load causing air pollution. In order to assess the impact of expansion and construction activities on the present national highway a detailed survey was conducted and a uniform stretch of the highway from Garamoura in Bilaspur to Nerchowk in Mandi district was selected under the jurisdiction of Himachal Pradesh situated between North latitude of $31^{\circ} 21^{\prime} 64^{\prime \prime}$ to $31^{\circ} 38^{\prime} 56^{\prime \prime}$ and East longitude of $76^{\circ} 56^{\prime} 77^{\prime \prime}$ to $76^{\circ} 46^{\prime} 46^{\prime \prime}$.

The study area experiences sub-tropical climate and there is a considerable variation in the seasonal temperature. In general, MayJune are the hottest months and DecemberJanuary, are the coldest ones in the region. The average annual rainfall in the region is $1200 \mathrm{~mm}$, the bulk of which is received during monsoon months (June-September) with few pre monsoon showers during early June period. The average maximum and minimum temperature varies from 22.50 to $38.77^{\circ} \mathrm{C}$ and 2.40 to $20.40^{\circ} \mathrm{C}$.

\section{Survey}

A field survey was conducted alongside the NH-21 from Garamoura in Bilaspur to Nerchowk in Mandi. For studying the distribution of species, random points were selected on both sides of the highway and $10 \mathrm{x}$ 
$10 \mathrm{~m}$ quadrates were laid in order to select the most commonly occurring species. Total, eleven commonly growing species were identified and selected for the study. Among all plant species, six were trees, viz. Dalbergia sisso, Grewia optiva, Leucaena leucocephala, Toona ciliata, Morus alba and Ficus palmata and five were shrubs, viz. Adhatoda vasica, Vitex negundo, Murraya koenigii, Carissa opaca and Debregeasia hypoleuca.

\section{Experimental details}

To complete the objectives of the present study the eleven identified commonly growing plant species were selected alongside from the edge of the National Highway. The influence of vehicular pollution on selected plants was studied in the month of October. The National Highway 21 was divided into four uniform segments and each was considered on replication. In total there were 11 treatments $(11 \mathrm{x} 1)$ which were replicated four times under factorial Randomised Block Design.

\section{Leaf analysis}

To assess the impact of vehicular pollution on various biochemical parameters of selected plant species fully matured leafs were collected in the morning hours. The collected leaf samples were carried to the laboratory for analysis in the ice box. The leaf samples were analysed for total chlorophyll, ascorbic acid, leaf extract $\mathrm{pH}$ and relative water content by using following standard procedures:

\section{Total chlorophyll content}

The leaf chlorophyll content was estimated by using method given by (Hiscox and Israelstam 1979). The fresh leaves were chopped to fine pieces under subdued light and $100 \mathrm{mg}$ of chopped leaf samples was placed in vials containing $7 \mathrm{ml}$ of dimethyl sulphoxide. These vials were incubated at $65^{\circ} \mathrm{C}$ for half an hour and extract was transferred to graduated test tube and the final volume was made to $10 \mathrm{ml}$ with dimethyl sulphoxide. Optical density values of the above extract was recorded on Spectrophotometer (Model-Spectronic-20) at $645 \mathrm{~nm}\left(\mathrm{~A}_{645}\right)$ and $663 \mathrm{~nm}\left(\mathrm{~A}_{663}\right)$ wavelength against dimethyl sulphoxide blank. Optical density of total chlorophyll content (T) is the sum of chlorophyll $\mathrm{A}_{645}$ density and chlorophyll $\mathrm{A}_{663}$ density. The total chlorophyll content was calculated by using formula:

Total chlorophyll content $\left(\mathrm{mgg}^{-1}\right)=\frac{20.0 \mathrm{~A}_{645}+8.02 \mathrm{~A}_{663}}{\mathrm{a} \times 1000 \times \mathrm{W}} \times \mathrm{V}$

Where;

$\mathrm{V}=$ volume of extract made

$\mathrm{a}=$ length of light path in cell (usually $1 \mathrm{~cm}$ )

$\mathrm{w}=$ weight of the sample taken

A645 is absorbance at $645 \mathrm{~nm}$

A663 is absorbance at $663 \mathrm{~nm}$

\section{Ascorbic acid}

The ascorbic acid content was estimated by using A. O. A. C. (1980) method. Fresh leaves $(10 \mathrm{~g})$ were homogenized in metaphosphoric acid solution. Volume was made to $100 \mathrm{ml}$. This solution was titrated against indophenols dye. Appearance of rose pink colour was the end point. The amount of ascorbic acid in milligrams per $100 \mathrm{~g}$ was calculated by using formula:

Ascorbic Acid $\left(\mathrm{mgg}^{-1}\right)=\frac{\text { Dye factor } \times \text { Titre reading } \times \text { Volume made }}{\text { Weight of leaves taken } \times \text { Volume taken for estimation }}$

\section{Dye factor}

Dye factor was determined by using the method by Ranganna (2008). For estimation of dye factor $5 \mathrm{ml}$ of the standard ascorbic acid solution was mixed with $5 \mathrm{ml}$ of metaphosphoric acid solution. The prepared indophenols dye was then titrated to a pink colour which persisted for 15 seconds. The dye factor was determined by the amount of 
ascorbic acid (mg) per $\mathrm{ml}$ of dye using the formula:

Dye Factor $=\frac{0.5}{\text { Titre Value }}$

\section{Leaf extract pH}

Recently matured leaves (5 g) were homogenized in $10 \mathrm{ml}$ deionised water and supernatant obtained after centrifugation was collected for determination of $\mathrm{pH}$ by using $\mathrm{pH}$ meter (Model- ESICO 1013) with buffer solution of $\mathrm{pH} 4$ and 9 (Barrs and Weatherly, 1962).

\section{Relative water content}

Relative water content of the samples was estimated using the method proposed by Singh (1977). Leaves were collected from different sites in polythene bags, then brought to the laboratory and were rinsed thoroughly and excess water was removed with filter paper.

Then three steps were followed: first, fresh weight (FW) was obtained by taking weight of fresh leaves; second, turgid weight (TW) was obtained by placing the leaves in a water filled Petri plate overnight, and in the morning the weight of turgid leaves was taken. In the third step, turgid leaves were dried in an oven at $70^{\circ} \mathrm{C}$ temperatures overnight and dry weight (DW) was recorded and was computed by using following equation:

Relative water content $(\%)=\frac{\mathrm{FW}-\mathrm{DW}}{\mathrm{TW}-\mathrm{DW}} \times 100$

Where, FW- Fresh weight,

TW- Turgid weight,

DW- Dry weight of leaf samples

\section{Air pollution tolerance index}

The air pollution tolerance index (APTI) was estimated by considering four biochemical parameters namely ascorbic acid, total chlorophyll, leaf extract $\mathrm{pH}$ and relative water content and was computed by using the following equation given by Singh and Rao (1983).

$$
\mathrm{APTI}=\frac{[\mathrm{A}(\mathrm{T}+\mathrm{P})]+\mathrm{R}}{10}
$$

Where, A- ascorbic acid ( $\left.\mathrm{mg} \mathrm{g}^{-1} \mathrm{FW}\right)$,

$\mathrm{T}$ - total chlorophyll ( $\left.\mathrm{mg} \mathrm{g}^{-1} \mathrm{FW}\right)$,

$\mathrm{P}$ - leaf extract $\mathrm{pH}$

$\mathrm{R}$ - relative water content $(\%)$ of the leaves

\section{Analytical tools employed}

The observations recorded for various biochemical parameters of plant species were subjected to statistical analysis under Randomized Block Design. Analysis of variance (ANOVA) was worked out and critical difference at 5 per cent level of significance was calculated as suggested by Cochran and Cox (1967).

\section{Results and Discussion}

\section{The chlorophyll content}

The plant species growing alongside the construction activities of National Highway were found to have significant variations in their leaf chlorophyll content (Table 1). The highest value of chlorophyll content $(3.81 \mathrm{mg}$ $\mathrm{g}^{-1}$ ) in case of tree species was recorded in the leaves of Toona ciliata. This was followed by Grewia optiva, Delbergia sisso, Leucaena leucocephala, Ficus palmata, with respective values of $3.14 \mathrm{mg} \mathrm{g}^{-1}, 3.08 \mathrm{mg} \mathrm{g}^{-1}, 3.08 \mathrm{mg} \mathrm{g}^{-}$ , $2.69 \mathrm{mg} \mathrm{g}^{-1}$ and lowest value of $2.68 \mathrm{mg} \mathrm{g}^{-1}$ in case of Morus alba. In case of shrubs maximum value of $2.89 \mathrm{mg} \mathrm{g}^{-1}$ was observed in Adhatoda vasica, followed by Debregeasia hypoleuca, Murraya koenigii and Carissa opaca, with values of $2.20 \mathrm{mg} \mathrm{g}^{-1}, 2.17 \mathrm{mg} \mathrm{g}^{-1}$ and $1.95 \mathrm{mg} \mathrm{g}^{-1}$. While, minimum value of $1.65 \mathrm{mg} \mathrm{g}^{-1}$ was observed in Vitex negundo.

Hence, total chlorophyll content of different plants varies from species to species due to 
photosynthetic process of plants which depends on leaf age, biotic-abiotic conditions and the level of vehicular pollutants (Katiyar and Dubey 2001; Tak and Kakde 2017; Sen et al., 2017). Higher values of chlorophyll content significantly reports that plant has high tolerance to air pollutants. Further, the high chlorophyll content may also be ascribed to the tolerance to the air pollutants. The results are in line with the findings of (Joshi et al., 1993; Santosh et al., 2008; Ninave et al., 2001).

\section{Ascorbic acid content}

Ascorbic acid is a powerful antioxidant which maintains cell division and cell membrane stability in plants during stress conditions by scavenging cytotoxic free radicals and reactive oxygen species produced due to photooxidation of $\mathrm{SO}_{2}$ to $\mathrm{SO}_{3}$ (Jyothi and Jaya 2010; Sanghi et al. 2015). The plant species growing alongside the construction activities of National Highway were found to have significant variations in their leaf ascorbic acid content in the leaves (Table 2). The ascorbic acid content in the leaves of selected plants was in the range of 2.34 to $4.42 \mathrm{mg} \mathrm{g}^{-1}$. The highest content of $4.42 \mathrm{mg} \mathrm{g}^{-1}$ in case of tree species was recorded in Toona ciliata which was followed by Delbergia sissio $\left(3.90 \mathrm{mg} \mathrm{g}^{-}\right.$ ${ }^{1}$ ), Leucaena leucocephala (3.85 $\mathrm{mg} \mathrm{g}^{-1}$ ), Ficus palmata (2.93 $\mathrm{mg} \mathrm{g}^{-1}$ ), Grewia optiva (2.90 $\left.\mathrm{mg} \mathrm{g}^{-1}\right)$ and lowest in Morus alba (2.61 $\left.\mathrm{mg} \mathrm{g}^{-1}\right)$. In case of shrubs maximum value of $3.55 \mathrm{mg} \mathrm{g}^{-1}$ was observed in case of Adhatoda vasica followed by Debregeasia hypoleuca (2.89 $\mathrm{mg} \mathrm{g}^{-1}$ ), Carissa opaca (2.81 $\left.\mathrm{mg} \mathrm{g}^{-1}\right)$, Murraya koenigii (2.55 $\left.\mathrm{mg} \mathrm{g}^{-1}\right)$, respectively, whereas the minimum value of $2.34 \mathrm{mg} \mathrm{g}^{-1}$ was recorded for Vitex negundo.

High values of ascorbic acid content in the plant species prevent them from the harmful effects of air pollutants (Kuddus et al., 2011). As Ascorbic acid content has inherent reducing power which is defensive against air pollution. Hence, this quality of plant leaves having high ascorbic acid content makes them more tolerant to air pollution. The results are in similar line with (Gholami et al., 2016; Ogunrotimi et al., 2017).

\section{Leaf extract pH}

The leaf extract $\mathrm{pH}$ plays a crucial role in regulating the pollution sensitivity in plants. (Das and Prasad 2010). The data pertaining to $\mathrm{pH}$ of plant species is cited in Table 3. A perusal of the data indicates that the selected plant species growing alongside the National Highway showed a significant variation in the leaf extract $\mathrm{pH}$. The leaf extract $\mathrm{pH}$ in the selected plants was in the range of 5.63 to 6.11. The highest value of 6.11 in tree species was recorded in Toona ciliata which is followed by Morus alba (6.09), Leucaena leucocephala (6.04), Delbergia sisso (5.99), Grewia optiva (5.96) and lowest value of 5.93 in Ficus palmata. In case of shrubs maximum value of 5.97 was recorded in Adhatoda vasica followed by Murraya koenigii (5.95), Vitex negundo (5.90), Debregeasia hypoleuca (5.87) respectively and minimum value in Carissa opaca (5.63). The higher values of $\mathrm{pH}$ have significant role in the plants which offers tolerance level in the plants to air pollutants (Bakiyaraj and Ayyappan 2014; Bora and Joshi 2014).

The results showed $\mathrm{pH}$ of leaf extract was acidic, which may be due to diffusion of gaseous air pollutants like $\mathrm{NO}_{2}, \mathrm{CO}_{2}$ and $\mathrm{SO}_{2}$ in the cell sap and when plants are suffering from air pollutants (especially $\mathrm{SO}_{2}$ ) as their cellular fluid would produce massive $\mathrm{H}^{+}$to react with $\mathrm{SO}_{2}$, which enters through stomata and intercellular space from air, so that $\mathrm{H}_{2} \mathrm{SO}_{4}$ is generated and then leaf $\mathrm{pH}$ reduces. The present results are in line with (GHassanen et al., 2016; Kaur and Nagpal 2017). It is also reported that, in the presence of an acidic pollutant $\left(\mathrm{SO}_{2}\right.$ and $\left.\mathrm{NO}_{2}\right)$, the leaf $\mathrm{pH}$ is 
reduced and the reducing rate is more in sensitive plants compared to that in tolerant plant species (Scholz and Reck 1977).

\section{Relative Water Content}

Relative Water Content (RWC) is an important factor with in plants which maintains its physiological balance under stressful conditions and enhances the tolerance capacity of the plants to the air pollution (Veni et al. 2014; Sen et al. 2017). The scrutiny of data in Table 4 revealed that the selected plant species growing alongside the National Highway showed a significant variation in RWC of the leaves. RWC in the plant leaves ranged from 56.64 to $81.48 \%$. Among the plant species the highest relative water content $(81.48 \%)$ in tree species was recorded in Toona ciliata, which was followed by Leucaena leucocephala (75.43 \%), Grewia optiva (73.32 \%), Dalberia sisso (70.33\%), Ficus carica (67.97\%), respectively whereas lowest in Moras alba (67.33 \%). In case of shrub species highest value was recorded in Adhatoda vasica $(68.35 \%)$ followed by Murraya koenigii (64.04 \%), Vitex negundo $(60.38 \%)$ and Carissa opaca $(58.28 \%)$. The lowest content of $56.64 \%$ was recorded in Debregeasia hypoleuca. The highest value of RWC in Toona ciliata may be ascribed due to its higher resistance capacity to stress conditions.

Table.1 Variation in total chlorophyll content $\left(\mathrm{mg} \mathrm{g}^{-1}\right)$ of selected plant species growing alongside National Highway expansion

\begin{tabular}{|l|c|c|}
\multicolumn{1}{|c|}{ Species } & \multicolumn{2}{c|}{$\begin{array}{c}\text { Total Chlorophyll } \\
\text { Content }\left(\mathbf{m g ~ g}^{-1}\right)\end{array}$} \\
\cline { 1 - 2 } & Mean & S.E. \\
\hline Trees & 3.08 & 0.06 \\
\hline Dalbergia sisso & 3.14 & 0.20 \\
\hline Grewia optiva & 3.08 & 0.15 \\
\hline Leucaena leucocephala & 3.81 & 0.13 \\
\hline Toona ciliata & 2.69 & 0.11 \\
\hline Ficus palmata & 2.69 & 0.07 \\
\hline Morus alba & & \\
\hline Shrubs & 2.17 & 0.29 \\
\hline Murraya koenigii & 1.65 & 0.24 \\
\hline Vitex negundo & 2.89 & 0.07 \\
\hline Adhatoda vasica & 1.95 & 0.22 \\
\hline Carissa opaca & 2.20 & 0.26 \\
\hline Debregeasia hypoleuca & 0.53 & \\
\hline C.D. (0.05) & 0.18 & \\
\hline SE(m) & 0.26 & \\
\hline SE(d) & 13.57 & \\
\hline C.V. & & \\
\hline
\end{tabular}


Table.2 Variation in ascorbic acid $\left(\mathrm{mg} \mathrm{g}^{-1}\right)$ of selected plant species growing alongside National Highway expansion

\begin{tabular}{|c|c|c|}
\hline \multirow[b]{2}{*}{ Species } & \multicolumn{2}{|c|}{ Ascorbic Acid (mg g $\left.{ }^{-1}\right)$} \\
\hline & Mean & S.E. \\
\hline \multicolumn{3}{|l|}{ Trees } \\
\hline Dalbergia sisso & 3.90 & 0.50 \\
\hline Grewia optiva & 2.90 & 0.45 \\
\hline Leucaena leucocephala & 3.85 & 0.28 \\
\hline Toona ciliata & 4.42 & 0.22 \\
\hline Ficus palmata & 2.93 & 0.21 \\
\hline Morus alba & 2.61 & 0.27 \\
\hline \multicolumn{3}{|l|}{ Shrubs } \\
\hline Murraya koenigii & 2.55 & 0.31 \\
\hline Vitex negundo & 2.34 & 0.58 \\
\hline Adhatoda vasica & 3.55 & 0.12 \\
\hline Carissa opaca & 2.81 & 0.13 \\
\hline Debregeasia hypoleuca & 2.89 & 0.18 \\
\hline C.D. (0.05) & 0.94 & \\
\hline $\mathrm{SE}(\mathrm{m})$ & 0.32 & \\
\hline $\mathrm{SE}(\mathrm{d})$ & 0.46 & \\
\hline C.V. & 20.45 & \\
\hline
\end{tabular}

Table.3 Variation in $\mathrm{pH}$ of selected plant species growing alongside National Highway expansion

\begin{tabular}{|l|l|l|}
\multicolumn{1}{|c|}{ Species } & \multicolumn{2}{c|}{ pH } \\
\hline Trees & Mean & S.E. \\
\hline Dalbergia sisso & 5.99 & 0.03 \\
\hline Grewia optiva & 5.96 & 0.02 \\
\hline Leucaena leucocephala & 6.04 & 0.02 \\
\hline Toona ciliata & 6.11 & 0.01 \\
\hline Ficus palmata & 5.93 & 0.03 \\
\hline Morus alba & 6.09 & 0.06 \\
\hline Shrubs & & \\
\hline Murraya koenigii & 5.95 & 0.03 \\
\hline Vitex negundo & 5.90 & 0.02 \\
\hline Adhatoda vasica & 5.97 & 0.03 \\
\hline Carissa opaca & 5.63 & 0.21 \\
\hline Debregeasia hypoleuca & 5.87 & 0.04 \\
\hline \multicolumn{1}{|c|}{ C.D.(0.05) } & 0.21 & \\
\hline SE(m) & 0.07 & \\
\hline CE(d) & 0.10 & \\
\hline C.V. & 2.43 & \\
\hline
\end{tabular}


Table.4 Variation in relative water content (\%) of selected plant species growing alongside National Highway expansion

\begin{tabular}{|c|c|c|}
\hline \multirow[b]{2}{*}{ Species } & \multicolumn{2}{|c|}{ Relative Water } \\
\hline & Mean & S.E. \\
\hline \multicolumn{3}{|l|}{ Trees } \\
\hline Dalbergia sisso & 70.33 & 0.74 \\
\hline Grewia optiva & 73.32 & 1.23 \\
\hline Leucaena leucocephala & 75.43 & 2.11 \\
\hline Toona ciliata & 81.48 & 2.22 \\
\hline Ficus palmata & 67.97 & 2.34 \\
\hline Morus alba & 67.33 & 2.21 \\
\hline \multicolumn{3}{|l|}{ Shrubs } \\
\hline Murraya koenigii & 64.04 & 3.70 \\
\hline Vitex negundo & 60.38 & 0.57 \\
\hline Adhatoda vasica & 68.35 & 0.42 \\
\hline Carissa opaca & 58.28 & 2.38 \\
\hline Debregeasia hypoleuca & 56.64 & 2.33 \\
\hline C.D. (0.05) & 6.08 & \\
\hline $\mathrm{SE}(\mathrm{m})$ & 2.09 & \\
\hline $\mathrm{SE}(d)$ & 2.96 & \\
\hline C.V. & 6.20 & \\
\hline
\end{tabular}

Table.5 Variation in air pollution tolerance index of selected plant species growing alongside National Highway expansion

\begin{tabular}{|c|c|c|}
\hline \multirow[b]{2}{*}{ Species } & \multicolumn{2}{|c|}{ APTI } \\
\hline & Mean & S.E. \\
\hline \multicolumn{3}{|l|}{ Trees } \\
\hline Dalbergia sisso & 10.56 & 0.46 \\
\hline Grewia optiva & 9.94 & 0.34 \\
\hline Leucaena leисосерhala & 11.05 & 0.40 \\
\hline Toona ciliata & 12.53 & 0.19 \\
\hline Ficus palmata & 9.33 & 0.22 \\
\hline Morus alba & 9.02 & 0.24 \\
\hline \multicolumn{3}{|l|}{ Shrubs } \\
\hline Murraya koenigii & 8.47 & 0.31 \\
\hline Vitex negundo & 7.79 & 0.41 \\
\hline Adhatoda vasica & 9.98 & 0.07 \\
\hline Carissa opaca & 7.96 & 0.37 \\
\hline Debregeasia hypoleuca & 7.98 & 0.16 \\
\hline C.D. $(0.05)$ & 0.917 & \\
\hline $\mathrm{SE}(\mathrm{m})$ & 0.316 & \\
\hline SE(d) & 0.447 & \\
\hline C.V. & 6.643 & \\
\hline
\end{tabular}


Table.7 Pearson's correlation coefficient (r) between biochemical parameters of leaves of eleven species collected alongside of National Highway

\begin{tabular}{|c|c|c|c|c|c|}
\hline \multirow[b]{2}{*}{ Plant Species } & \multicolumn{5}{|c|}{ Pearson's correlation coefficient } \\
\hline & & $\mathbf{T}$ & $\mathbf{A}$ & $\mathbf{R}$ & $\mathbf{P h}$ \\
\hline \multirow[t]{4}{*}{ Dalbergia sisso } & Dalbergia sisso & -0.950 & 1 & & \\
\hline & $\mathbf{R}$ & -0.551 & 0.308 & 1 & \\
\hline & pH & 0.368 & -0.296 & 0.114 & 1 \\
\hline & APTI & -0.973 & $0.990^{*}$ & 0.438 & -0.236 \\
\hline \multirow{4}{*}{ Grevia optiva } & Grevia optiva & -0.997 & 1 & & \\
\hline & $\mathbf{R}$ & 0.073 & -0.063 & 1 & \\
\hline & pH & $0.775^{*}$ & -0.741 & $0.563 *$ & 1 \\
\hline & APTI & -0.931 & $0.940^{*}$ & 0.280 & -0.506 \\
\hline \multirow[t]{4}{*}{ Leucaena leucocephala } & Leucaena leucocephala & $0.448 *$ & 1 & & \\
\hline & $\mathbf{R}$ & -0.241 & 0.405 & 1 & \\
\hline & pH & $0.454 *$ & -0.216 & -0.972 & 1 \\
\hline & APTI & 0.319 & $0.910^{*}$ & $0.731 *$ & -0.563 \\
\hline \multirow{4}{*}{ Toona ciliata } & Toona ciliata & 0.327 & 1 & & \\
\hline & $\mathbf{R}$ & -0.872 & -0.530 & 1 & \\
\hline & pH & $0.531 *$ & $0.968^{*}$ & -0.634 & 1 \\
\hline & APTI & -0.320 & $0.650 *$ & 0.285 & $0.557 *$ \\
\hline \multirow[t]{4}{*}{ Ficus palmata } & Ficus palmata & $0.596^{*}$ & 1 & & \\
\hline & $\mathbf{R}$ & 0.244 & -0.592 & 1 & \\
\hline & pH & -0.849 & -0.839 & 0.275 & 1 \\
\hline & APTI & $0.877 *$ & 0.251 & $0.631 *$ & -0.492 \\
\hline \multirow[t]{4}{*}{ Morus alba } & Morus alba & -0.067 & 1 & & \\
\hline & $\mathbf{R}$ & 0.209 & -0.425 & 1 & \\
\hline & pH & -0.612 & -0.691 & $0.436^{*}$ & 1 \\
\hline & APTI & 0.166 & 0.528 & 0.544 & -0.255 \\
\hline \multirow[t]{4}{*}{ Murraya koenigii } & Murraya koenigii & -0.200 & 1 & & \\
\hline & $\mathbf{R}$ & $0.776^{*}$ & -0.750 & 1 & \\
\hline & pH & -0.810 & -0.161 & -0.511 & 1 \\
\hline & APTI & $0.976 *$ & -0.097 & $0.729 *$ & -0.917 \\
\hline \multirow[t]{4}{*}{ Vitex negundo } & Vitex negundo & -0.382 & 1 & & \\
\hline & $\mathbf{R}$ & $0.925 *$ & -0.275 & 1 & \\
\hline & pH & $0.774 *$ & -0.815 & $0.776^{*}$ & 1 \\
\hline & APTI & -0.176 & $0.976^{*}$ & -0.060 & -0.673 \\
\hline \multirow[t]{4}{*}{ Adhatoda vasica } & Adhatoda vasica & -0.783 & 1 & & \\
\hline & $\mathbf{R}$ & $0.993 *$ & -0.850 & 1 & \\
\hline & pH & $0.921 *$ & -0.539 & $0.873 *$ & 1 \\
\hline & APTI & -0.160 & $0.739 *$ & -0.275 & 0.143 \\
\hline \multirow[t]{4}{*}{ Carissa opaca } & Carissa opaca & -0.142 & 1 & & \\
\hline & $\mathbf{R}$ & 0.217 & $0.854^{*}$ & 1 & \\
\hline & pH & 0.965 & -0.205 & 0.246 & 1 \\
\hline & APTI & 0.429 & $0.783^{*}$ & $0.972 *$ & 0.430 \\
\hline \multirow[t]{4}{*}{ Debregeasia hypoleuca } & Debregeasia hypoleuca & -0.769 & 1 & & \\
\hline & $\mathbf{R}$ & -0.045 & -0.484 & 1 & \\
\hline & $\mathbf{p H}$ & 0.026 & 0.253 & -0.875 & 1 \\
\hline & APTI & -0.254 & -0.162 & $0.926 *$ & -0.958 \\
\hline
\end{tabular}

$A$ Ascorbic Acid, $R$ Relative water content, $T$ Total chlorophyll content, APTI air pollution tolerance index *Significant ay $\mathrm{p} \leq 0.05$. 
Figure.1 Location map of the study area

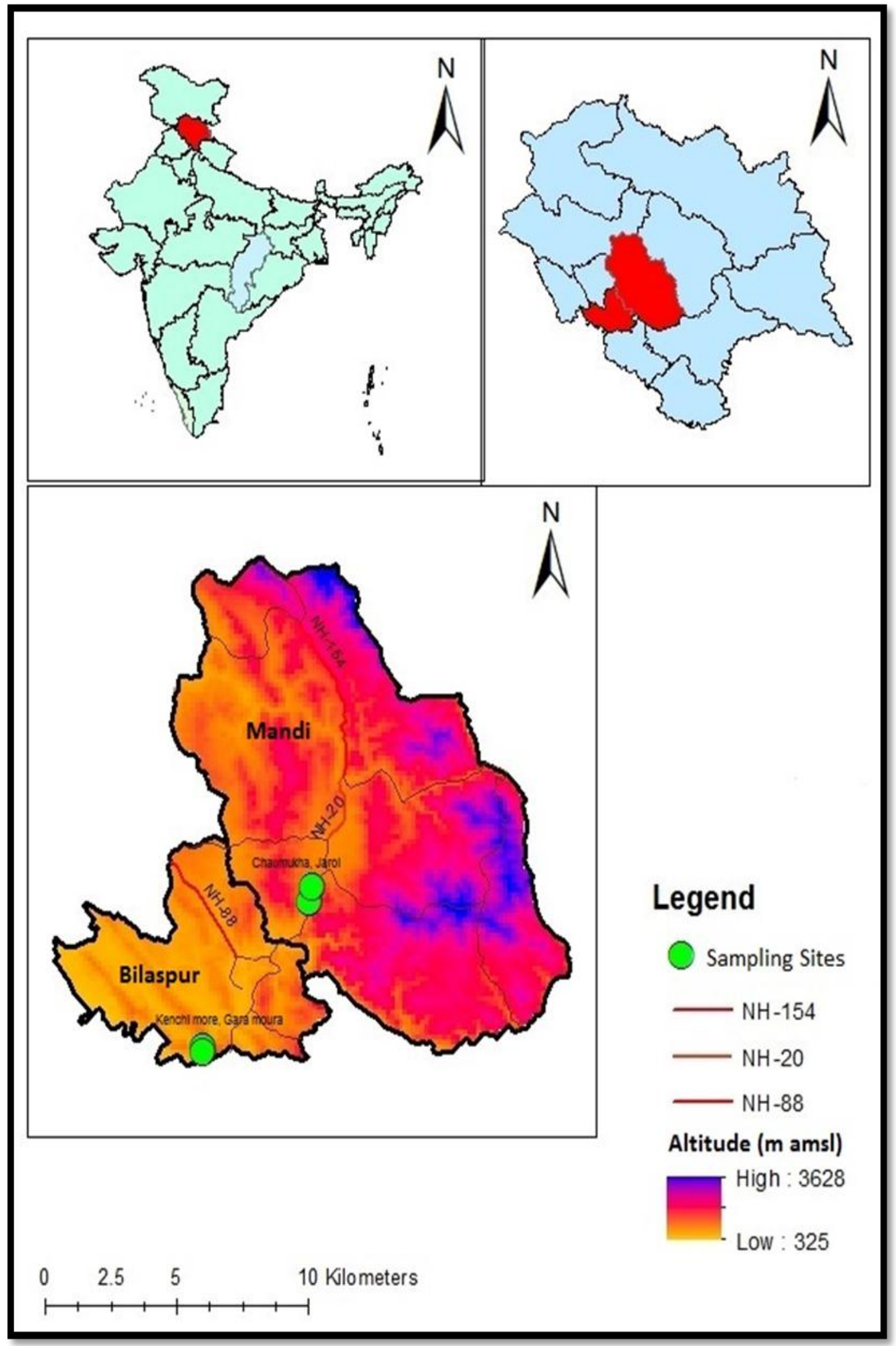


Figure.3 Linear regression analysis of individual variables (biochemical parameters) with APTI values. a) pH vs APTI, b) Relative water content (\%) vs APTI, c) Total chlorophyll content (mg $\mathrm{g}^{-1}$ ) vs APTI and d) Ascorbic acid content vs APTI
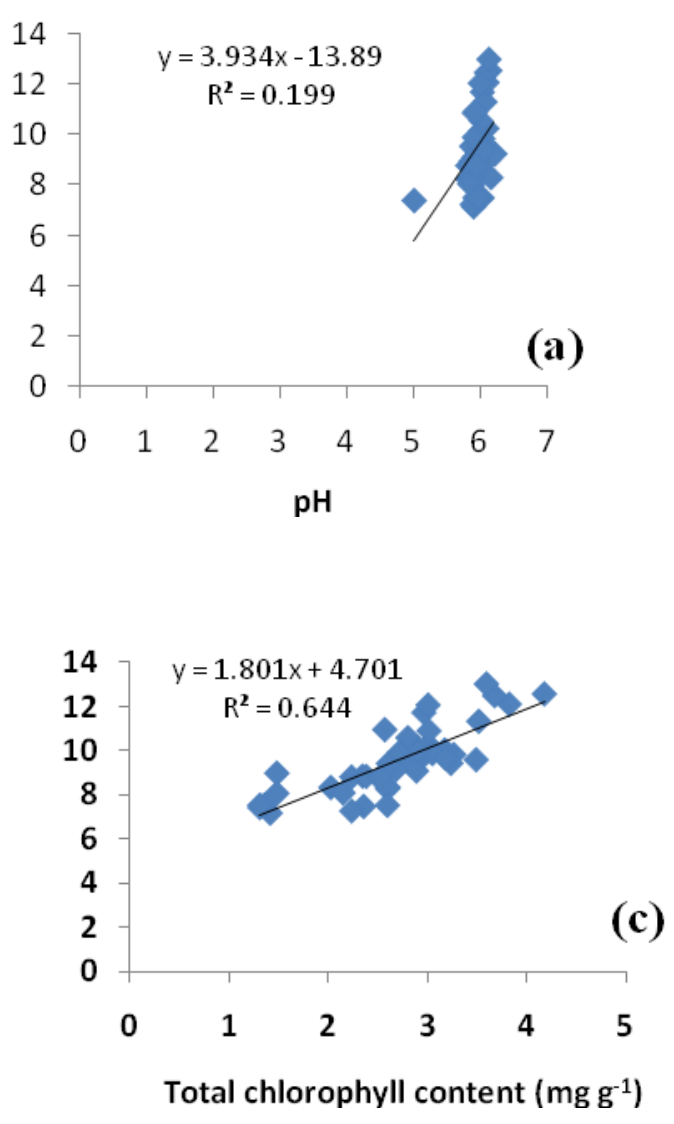
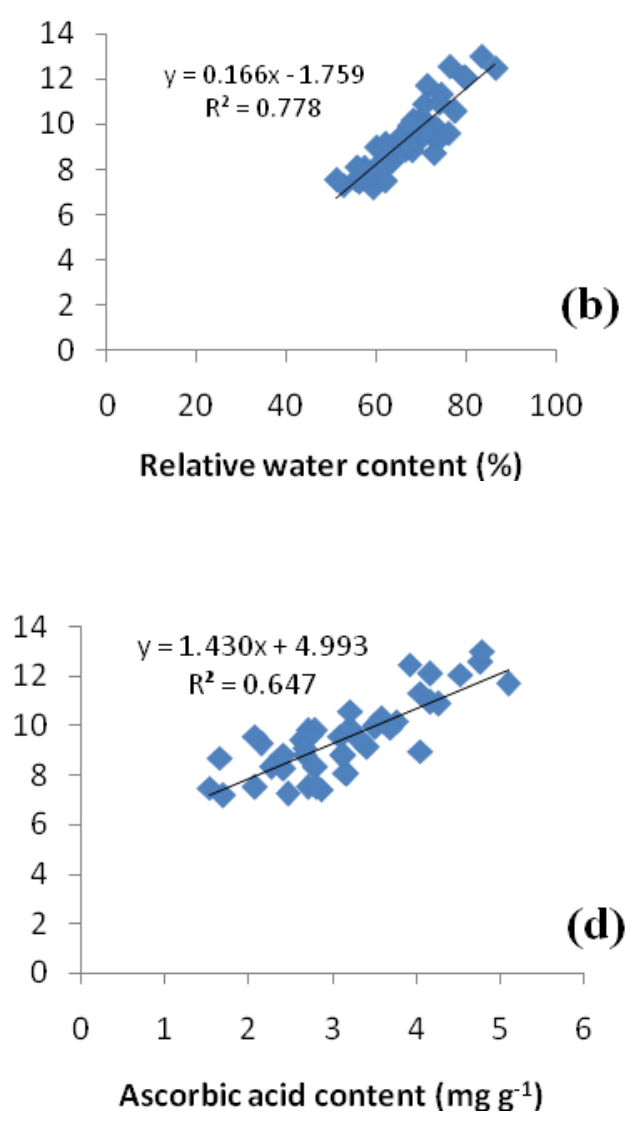

Biochemical Parameters

High RWC content in plants ensures the maintenance of the physiological balance under stresses such as air pollution (Buchchi et al., 2013; Sharma et al., 2017a). Also, higher water content in plants can dilute acidity inside the leaf cell sap and improve its drought tolerance (Palit et al., 2013; Rai et $a l ., 2013)$. Therefore, it is likely valedictory that the plant species having high RWC have high capacity of tolerance of air pollution.

\section{Air pollution toleration index (APTI)}

The selected plant species growing alongside the national highway expansion were found to have significant variations in the air pollution tolerance index (Table 5). The APTI of selected tree species followed the order of Toona ciliata > Leucaena leucocephala > Dalbergia sisso > Grevia optiva > Ficus palmata > Morus alba with their respective values of 12.53, 11.05, 10.56, 9.94, 9.33 and 9.02. Also, the APTI of most shrubs was higher than those tree species such as Adhatoda vasica > Murraya koenigii > Debregeasia hypoleuca > Carissa opaca > Vitex negundo with their respective values of $9.98,8.47,7.98,7.96$ and 7.79 suggesting that 
shrubs in general, were more tolerant to air pollution than trees. Higher values of APTI represent the potential of plants to facilitate in polluted areas and contribute as an air pollution synthesizer (sink) (Joshi and Swami, 2007; Sharma et al. 2017b; Kumari and Deswal 2017). The variation in the tolerance of the plant species of a region to stress conditions has also been reported by (Agbaire and Esiefarienrhe 2009; Kapoor and Bhardwaj 2016; Pandit et al. 2017).

\section{Linear regression analysis}

APTI of plant species was found to increase, which is mainly due to increase in the values of $\mathrm{pH}$, relative water content, total chlorophyll content and ascorbic acid content of plant leaves.

Therefore a linear regression analysis was performed to ascertain which of leaf biochemical parameter had a greater influence on APTI of plant species. Analysis showed significantly strong positive impact of ascorbic acid content $\left(\mathrm{R}^{2}=0.647\right)$ on APTI. However, it was concluded that the higher values of ascorbic acid were found in all plant species as compared to $\mathrm{pH}$, relative water content and total chlorophyll content, which indicated that ascorbic acid content impacted on the APTI for screening out the most tolerant plant species (Figure 3).

\section{Pearson's correlation coefficient analysis}

The correlation analysis shows the relationship between the four biochemical parameters and APTI for each plant species. The scrutiny of analysis presented in Table 6 revealed a significant positive correlation between APTI and ascorbic acid content in case of Dalbergia sisso $(\mathrm{r}=0.990)$, Grevia optiva $(\mathrm{r}=0.940)$, Leucaena leucocephala $(\mathrm{r}$ $=0.910)$, Toona ciliata $(\mathrm{r}=0.650)$, Vitex negundo ( $\mathrm{r}=0.976)$, Adhatoda vasica $(\mathrm{r}=$ $0.739)$ and Carissa opaca $(\mathrm{r}=0.783)$.
APTI of Ficus palmata $(\mathrm{r}=0.631)$, Leucaena leucocephala $(\mathrm{r}=0.731)$, Murraya koenigii $(\mathrm{r}$ $=0.729)$, Carissa opaca $(\mathrm{r}=0.972)$, Debregeasia hypoleuca $(\mathrm{r}=0.926)$ showed a significant positive correlation at $\mathrm{p} \leq 0.05$ with relative water content.

Also, a significant positive correlation at $\mathrm{p} \leq$ 0.05 between APTI and total chlorophyll content in case of Ficus carica $(\mathrm{r}=0.877)$ and Murraya koenigii $(\mathrm{r}=0.729)$.

Overall analysis stated that each parameter plays a significant role in the evaluation of air pollution tolerance index of particular plant species. Especially ascorbic acid content and relative water content of leaves had a special affect in the higher resistance to stress conditions.

In conclusion, the present study inferred that tree species Toona ciliata and Leucaena leucocephala and shrubs namely Adhatoda vasica and Murraya koenigii emerged as tolerant species growing alongside the $\mathrm{NH}-$ 21. It was concluded that air pollution tolerance index increased with increase in biochemical parameters such as total chlorophyll content, ascorbic acid, relative water content and $\mathrm{pH}$ and hence these plant species need to be recommended for plantation alongside the national highway falling in sub-tropical region of Himachal Pradesh.

\section{References}

Agbaire PO, Esiefarienrhe E. 2009. Air Pollution tolerance indices (APTI) of some plants around Otorogun Gas Plant in Delta State, Nigeria. J App Sci Env Man. 13(1): 11-14.

A O A C. 1980. Official methods of analysis chemist, 13th ed. (W. Horwitz, ed.) Asso Analyt Chem. 83: 617-623.

Barrs HD, Weatherly PE. 1962. A reexamination of the relative turbidity 
technique for estimating water deficit in leaves. Au J Bio Sci. 15: 413-42.

Bakiyaraj R, Ayyappan D. 2014. Air pollution tolerance index of some terrestrial plants around an industrial area. International $\mathbf{J}$ Mod Res Rev. 2(1): 1-7.

Bora M, Joshi N. 2014. A study on variation in biochemical aspects of different tree species with tolerance and performance index. The Bios. 9(1): 59-63.

Buchchi BG, Nazaneen PS, Naveen KK, Sridhar RM. 2013. Evaluation of air pollution tolerance indices of plant species growing in the vicinity of cement industry and Yogi Vemana University campus. Ind $\mathbf{J}$ Adv Chem Sci. 2(1): 16-20.

Cochran WG and Cox GM. 1967. Experimental design. New York. Wiley Inc.

Das S, Prasad P. 2010. Seasonal variation in air pollution tolerance indices and selection of plant species for industrial areas of Rourkela. Ind J Env Pro. 30: 978-988.

GHassanen RA, Morsy AA, Saleh HA. 2016. Leaf dust accumulation and air pollution tolerance indices of three plant species exposed to urban particulate matter pollution from a fertilizer factory. Int $\mathbf{J}$ Plant Res. 29 (3):146-151.

Gholami A, Mojiri A, Amini H. 2016. Investigation of the air pollution tolerance index (APTI) using some plant species in Ahvaz region. J An Plant Sci. 26(2): 475480.

Gidde MR, Sonawane PP. 2012. Assessment of traffic related air pollution and ambient air quality of metropolitan cities (Case study of Pune city). IOSR J Eng. 2(6): 1382-1390

Hiscox JD, Israelstam GF. 1979. A method for the extraction of chlorophyll from leaf tissue without maceration. Can J Bot. 57: 1332-1334.

Joshi OP, Pawar K, Wagela DK. 1993. Air quality monitoring of Indore city with special reference to $\mathrm{SO}_{2}$ and tree barks $\mathrm{pH}$. J Env Bio. 14(2): 157-162.

Jyothi JS, Jaya DS. 2010. Evaluation of air pollution tolerance index of selected plant species along roadsides in
Thiruvanthapuram, Kerala. J Env Bio. 31:379-386.

Kapoor T, Bhardwaj SK. 2016. Assessment of air pollution tolerance index of plants growing alongside National Highway (21) of Himachal Pradesh in India. The Eco. 10(3\&4): 419-426.

Katiyar V, Dubey PS. 2001. Sulphur dioxide sensitivity on two stage of leaf development in a few tropical tree species. Ind $\mathrm{J}$ Env Toxic. 11: 78-81.

Kaur M, Nagpal AK. 2017. Evaluation of air pollution tolerance index and anticipated performance index of plants and their application in development of green space along the urban areas. Env Sci Poll Res Inter. 24:18881-18895.

Khandar C, Kosankar S. 2014. A review of vehicular pollution in urban India and its effects on human health. J Adv Lab Res Bio. 5(3): 54-61.

Kuddus M, Kumari R, Ramteke PW. 2011. Studies on air pollution tolerance of selected plants in Allahabad city, India. J Env Res Manag. 2(3): 42-46.

Kumari J, Deswal S. 2017. Assessment of air pollution tolerance index of selected plants unveil to traffic roads of Noida, Uttar Pradesh. Inter J Em Techno. 8(1): 179-184.

Mondal D, Gupta S, Datta JK. 2011. Anticipated performance index of some tree species considered for green belt development in an urban area. Inter Res $\mathbf{J}$ Plant Sci. 2(4): 99-106.

Ninave SY, Chaudhari PR, Gajghate DG, Tarar JL, Foliar AD. 2001. Biochemical features of plants as indicators of air pollution. Bull Env Cont Toxico. 67(1): 133-140.

Ogunrotimi DG, Adebola SI, Akinpelu BA, Awotoye OO. 2017. Evaluation of biochemical and physiological parameters of the leaves of tree species exposed to vehicular emissions. J App Life Sci Inter. 10(4): 1-9.

Palit D, Kar D, Misra P, Banerjee A. 2013. Assessment of air quality using several biomonitor of selected sites of Duragapur, Burdwan district byAir Pollution Tolerance 
Index approach. Ind J Sci Res. 4(1):149152.

Pandit J, Sharma AK, Sood A, Bhardwaj SK. 2017. Anticipated performance index of commonly growing plant species along the National Highway (NH-7) in Nahan to Paonta Sahib stretch in Himachal Pradesh, India. Poll Res. 36(1): 97-103.

Rai PJ, Panda LLS, Chutia BM, Singh MM. 2013. Comparative assessment of Air Pollution Tolerance Index (APTI) in the industrial (Rourkela) and non industrial area (Aizawl) of India: an ecomanagement approach. Af J Env Sci Tech. 7(10): 944948.

Rangana S. 2008. Handbook of analysis and quality control for fruit and vegetable products. $2^{\text {nd }}$ edition. Tata McGraw-Hill Publishing Company Ltd., New Delhi. p. 106-107.

Sanghi SB, Sharma C, Sanghi SK. 2015. Comparison of APTI valuess of some medicinal plants of industrial areas and Ratapani wild life sanctuary in Raisen district of Madhya Pradesh. International J Phar Life Sci. 6(1): 4157-4160.

Santosh K, Prajapati B, Trapathi. 2008. Anticipated Performance Index of some tree species considered green belt development in and around an urban area: A case study of Varanasi city, India. J Env Manag. 88: 1343-1349.

Scholz F, Reck S. 1977. Effects of acids on forest trees as measured by titration in vitro inheritance of buffering capacity in PiceaAbies. Wat Air Soil Poll. 8: 41-45.

Sen A, Khan I, Kundu D, Das K, Datta JK. 2017. Ecophysiological evaluation of tree species for biomonitoring of air quality and identification of air pollution tolerant species. Env Mon Assess. 189: 262.

Seyyednjad SM, Majdian K, Koochak H, Niknejad M. 2011. Air pollution tolerance indices of some plants around industrial zone in south of Iran. Asian J Bio Sci. 4:300-305.

Sharma B, Sharma S, Bhardwaj SK. 2017a. Effect of pollution on relative water content in temperate species growing along National Highway 5 in Himachal Pradesh. In: Proceedings of IEEEFORUM International Conservation, $20^{\text {th }}$ August, 2017, New Delhi, India. pp 32-35.

Sharma B, Sharma S, Bhardwaj SK, Kaur L, Sharma A. 2017b. Evaluation of air pollution tolerance index (APTI) as a tool to monitor pollution and green belt development: A review. J App Nat Sci. 9(3): 1637-1643.

Singh SK. 1977. Practical Plant Physiology. Kalayani Publishers. New Delhi, 226 pp.

Singh SK, Rao DN. 1983. Evaluation of plants for their tolerance to air pollution. In: Proceedings symposium on Air Pollution control held at IIT, Delhi, pp. 218-224.

Sisodia A, Dutta S. 2016. Air pollution tolerance index of certain plant species: a study of National Highway no-8, India. J Env Res Dev. 10(4): 723-728.

Tak AA, Kakde UB. 2017. Assessment of air pollution tolerance index of plants: A comparative study. Inter J Ph Pharm Sci. 9(7): 83-89.

Veni K, Marimuthu, Lavanya K. 2014. Air pollution tolerance index of plants a comparative study. Inter $\mathrm{J}$ Ph Pharm Sci. 6(5): 320-324.

\section{How to cite this article:}

Abhay Sharma, Satish Kumar Bhardwaj, Meena Thakur, Uday Sharma and Subhash Sharma. 2018. Identification of Tolerant Plant Species Growing Alongside National Highway-21 in Himachal Pradesh, India. Int.J.Curr.Microbiol.App.Sci. 7(06): 2762-2775.

doi: https://doi.org/10.20546/ijcmas.2018.706.325 